\title{
Bimetallic Ce/Zr UiO-66 Metal-Organic Framework Nanostructures as Peptidase and Oxidase Nanozymes
}

\author{
Alexandra Loosen, ${ }^{\S}$ Charlotte Simms, ${ }^{\S}$ Simon Smolders, Dirk E. De Vos, and Tatjana N. Parac-Vogt*
}

\begin{abstract}
The catalytic activity of metal-organic frameworks (MOFs) toward peptides and proteins provides an attractive route for the development of nanozymes for applications in biotechnology and proteomics, particularly in the field of protein identification using mass spectrometry. Here, we report that carefully tuning the $\mathrm{Ce} / \mathrm{Zr}$ metal ratio is a promising strategy to overcome structural limitations that originate from the high connectivity of the $\mathrm{Zr}_{6}$ node and also increase the peptidase activity of the MOF while preserving the material's nano-topology and stability. A series of bimetallic Ce/Zr-UiO-66 MOFs, in which

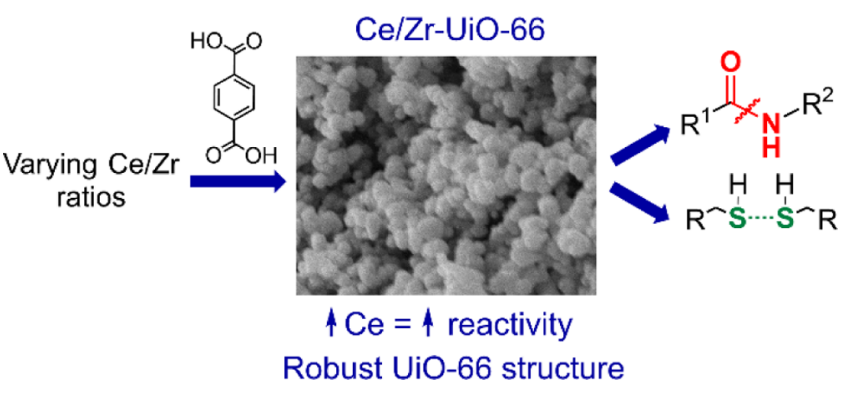
the amount of Ce was systematically varied from 28 to $87 \mathrm{~mol} \%$, have been shown to efficiently catalyze peptide bond hydrolysis in a large variety of peptides with different functional groups, demonstrating their nanozyme potential. Detailed kinetic analysis of the hydrolysis of peptide bonds with a range of Ce/Zr MOFs suggests that among the different metallic clusters present in UiO-66, the $\mathrm{Ce}_{6}$ clusters have superior reactivity compared to the $\mathrm{CeZr}_{5}$ sites. In addition to increasing the catalytic potency of the MOF toward peptide bond hydrolysis, the introduction of Ce(IV) also broadens the reaction scope of MOF catalysts. Selective oxidation of the thiol sidechains and the formation of disulfide bridges have been observed at physiological $\mathrm{pH}$ both in cysteine and in glutathione tripeptide as substrates. The rate of oxidation is directly proportional to the amount of Ce present in the MOF, demonstrating that the introduction of Ce into these nanomaterials is a promising strategy to introduce oxidase activity toward biologically relevant substrates. In addition to this, adsorption of dipeptides onto MOF nanomaterials has been studied for the first time. These studies revealed a close link between the nature of peptide side chains and the extent of their adsorption, which has a direct influence on their ability to act as substrates in MOF-catalyzed reactions.
\end{abstract}

KEYWORDS: hydrolysis, oxidation, peptides, metal-organic frameworks, nanozymes

\section{INTRODUCTION}

Metal-organic frameworks (MOFs) are an emerging class of porous nanomaterials with a large potential in the field of heterogeneous catalysis. ${ }^{1}$ MOFs are formed from metal ions or metal-oxygen clusters joined together by organic linkers, resulting in highly porous crystal structures. Using different metal clusters and types of linkers results in many different MOF structures with diverse properties, tunable pore diameters, and particle sizes that can range from a few nanometers to micrometers in diameter. ${ }^{2}$ The high internal surface areas of MOFs, which arise from the presence of pores, are key to their use as catalysts, as well as in the fields of adsorption, ${ }^{3-5}$ drug delivery, ${ }^{6}$ and enzyme immobilization. ${ }^{7}$

In particular, the incorporation of Lewis acidic metal ions like $\mathrm{Zn}(\mathrm{II}), \mathrm{Ce}(\mathrm{IV}), \mathrm{Ti}(\mathrm{IV})$, and $\mathrm{Zr}(\mathrm{IV})$ in the secondary building blocks endows MOFs with excellent catalytic properties. $^{8-11}$ Recently, we discovered that $\mathrm{Zr}$ (IV)-MOFs act as excellent catalysts for hydrolytic cleavage of the peptide bond. ${ }^{12-14}$ Selective and efficient cleavage of peptide bonds is of great importance in different areas of biotechnology and proteomics. For protein identification and de novo peptide sequencing via mass spectrometry (MS), proteins must be digested into shorter fragments to be identified using MS. However, this is a challenging task as peptide bonds are highly stable and this is reflected in their very long half-life for hydrolysis, which is up to 600 years at physiological temperature and $\mathrm{pH}^{15,16}$ Most of the artificial metalloproteases developed so far are based on homogeneous catalysis $^{17-21}$ and often exhibit limited reactivity under physiological $\mathrm{pH}$ conditions. ${ }^{22-26}$ Among many metals that have been proposed as catalysts for the hydrolytic cleavage of peptide bonds, ${ }^{15,27-29} \mathrm{Zr}(\mathrm{IV})$ is particularly effective due to its strong Lewis acidity, large coordination numbers, flexible coordination geometries, and fast ligand-exchange kinetics. ${ }^{15}$ However, $\mathrm{Zr}(\mathrm{IV})$ salts are prone to hydrolysis at neutral $\mathrm{pH}$, 
resulting in the formation of insoluble gels, which greatly impairs reactivity. ${ }^{30,31}$ We have shown that the incorporation of $\mathrm{Zr}(\mathrm{IV})$ into metal-oxo clusters such as polyoxometalates (POMs) results in stable and selective artificial peptidases which operate at physiological $\mathrm{pH}^{32-38}$ However, the solubility of $\mathrm{Zr}(\mathrm{IV})$-POMs in water hinders recovery of the catalyst and product purification. Therefore, the use of heterogeneous catalyst nanozymes has recently emerged as a promising alternative. ${ }^{12-14,39}$ MOF nanozymes are an area of great interest due to their tailorability and potential to mimic catalytic sites of naturally occurring enzymes. For example, by forming a MOF@COF (covalent-organic framework) construct with the MOF $\mathrm{NH}_{2}-\mathrm{MIL}-88 \mathrm{~B}$ and a "spiky" COF, a peroxidase-type nanozyme was shown to efficiently inhibit bacteria, with the COF acting to enhance bacteria-construct interactions. $^{40}$

We recently reported that $\mathrm{Zr}(\mathrm{IV})$-based MOFs, which include 6-, 8-, and 12-connected MOF-808, NU-1000, and UiO-66, respectively, act as efficient catalysts for hydrolysis of the peptide bond in short peptides and in hen egg white lysozyme protein. ${ }^{12-14}$ Depending on the MOF, an increase in the reaction rate of up to 3 orders of magnitude was achieved compared to the homogeneous hydrolysis with $\mathrm{Zr}(\mathrm{IV})$ substituted POM complexes. ${ }^{32}$ More strikingly, this translates to a large increase in peptide bond hydrolysis compared to the uncatalyzed hydrolysis, which in glycylglycine has a half-life of 6 years under similar conditions.

The few recent examples of MOF-catalyzed peptide bond hydrolysis were all based on the $\mathrm{Zr}_{6}$-cluster as a catalytic site in the MOF structure. The $\mathrm{Zr}_{6}$-cluster $\left[\mathrm{Zr}_{6}\left(\mu_{3}-\mathrm{O}\right)_{4}\left(\mu_{3}-\mathrm{OH}\right)_{4}\right]^{12+}$, which is the secondary building block of UiO-66, consists of $\mu_{3}$-bridging oxido and hydroxyl groups between $\mathrm{Zr}$ (IV) centers, which are 12-connected by the linker 1,4-benzenedicarboxylate (BDC). Such an arrangement results in a $\mathrm{Fm} 3 \mathrm{~m}$ framework with $11 \AA$ octahedral and $8 \AA$ tetrahedral pores (Figure 1). ${ }^{42}$ Among the examined MOFs, UiO-66 is

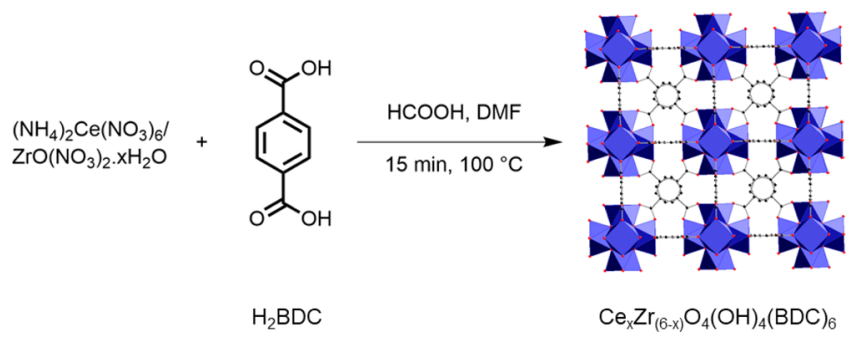

Figure 1. Synthesis of bimetallic $\mathrm{Ce}_{x} \mathrm{Zr}_{(6-x)} \mathrm{O}_{4}(\mathrm{OH})_{4}(\mathrm{BDC})_{6}$. The crystal structure is based on the analogous $\mathrm{Zr}$-UiO- $66 .{ }^{57}$

particularly interesting as a catalyst due to its unique robustness, with reported stability up to $500{ }^{\circ} \mathrm{C}$ or $\mathrm{pH} 11$ without loss of structure. ${ }^{43,44}$ Unfortunately, despite being the most stable among the $\mathrm{Zr}_{6}$-based MOFs, UiO-66 is the least active nanomaterial tested for peptide bond hydrolysis ${ }^{12-14}$ most likely due to the 12 -connected $\mathrm{Zr}_{6}$ node, which leaves few coordination sites open for catalysis. A possible way to increase the reactivity of UiO-66, while preserving its nano-topology, is by introducing other Lewis acid metals with higher coordination numbers into the core cluster. ${ }^{45}$ Specifically, substitution of one or more of the $\mathrm{Zr}(\mathrm{IV})$ ions in the $\left[\mathrm{Zr}_{6}\left(\mu_{3}\right.\right.$ $\left.\mathrm{O})_{4}\left(\mu_{3}-\mathrm{OH}\right)_{4}\right]^{12+}$ secondary building unit for another metal, like $\mathrm{Ce}(\mathrm{IV})$, can potentially enhance its nanozymatic peptidase potential because Ce(IV) has shown a superior activity toward peptide bond hydrolysis in previous studies. ${ }^{27,46-50}$ Moreover, compared to its $\mathrm{Zr}(\mathrm{IV})$ analogue, the pure $\mathrm{Ce}(\mathrm{IV})$-MOF and $\mathrm{Ce}(\mathrm{IV})$-doped $\mathrm{Zr}(\mathrm{IV})$-MOFs have shown better reactivity in catalyzing degradation of organophosphorus-based nerve agents through hydrolysis reactions. ${ }^{51,52}$

In addition to increasing the catalytic potency of the MOF toward peptide bond hydrolysis, the introduction of $\mathrm{Ce}(\mathrm{IV})$ could also broaden the scope of MOF catalysts because the redox activity of $\mathrm{Ce}(\mathrm{IV})$ could be exploited for catalysis of other reaction types. The redox activity of Ce-UiO-66 and its dimethyl-substituted analogue has been reported in the oxidation reactions of benzyl alcohol, ${ }^{8}$ olefins, ${ }^{53}$ and in oxidative coupling of thiophenols. ${ }^{54}$ However, the redox activity of MOFs toward biologically relevant building blocks has been scarcely explored, especially considering that redox reactions are essential in many biological processes, such as photosynthesis, metabolism, and DNA repair. ${ }^{55}$ Due to redox chemistry of the $\mathrm{Ce}(\mathrm{IV}) / \mathrm{Ce}(\mathrm{III})$ couple, $\mathrm{Ce}(\mathrm{IV})$-MOFs might be suitable as catalysts for biologically relevant reactions, such as the oxidation of amino acids and peptides. ${ }^{48}$ Recently, a Cebased MOFzyme, AU-1 has been shown to be highly efficient at inducing oxidative stress in airborne fungi in a speciesdependent manner, paving the way for redox active MOFs to be used in nanomedicine. ${ }^{56}$

In this work, we set out to explore the potential of $\mathrm{Ce}$ (IV)based MOFs as nanozymes toward amino acids and peptides. We specifically aimed to extend the scope of bimetallic Ce/ZrUiO-66 MOFs both as an artificial nanozyme for the hydrolysis of peptide bonds and as a redox active material, and to explore the effect of the $\mathrm{Ce}(\mathrm{IV})$ to $\mathrm{Zr}(\mathrm{IV})$ molar ratio on the catalytic and redox activity within this nanomaterial.

\section{EXPERIMENTAL PROCEDURES}

Synthesis of MOF Catalysts. $\mathrm{Zr}_{6} \mathrm{O}_{4}(\mathrm{OH})_{4}(\mathrm{BDC})_{6}$. A $500 \mathrm{~mL}$ VWR pressure plus+ bottle was charged with $\mathrm{ZrCl}_{4}(0.625 \mathrm{~g}, 2.68$ $\mathrm{mmol}), 5 \mathrm{~mL}$ of $\mathrm{HCl}(37 \%)$, and $25 \mathrm{~mL}$ of $\mathrm{N}, \mathrm{N}$-dimethylformamide (DMF). A second $100 \mathrm{~mL}$ VWR pressure plus+ bottle was charged with 1,4-benzenedicarboxylic acid $(0.615 \mathrm{~g}, 3.70 \mathrm{mmol})$ and $50 \mathrm{~mL}$ of DMF. Both bottles were sonicated until a homogeneous solution was obtained. After the solutions were prepared, 1,4-benzenedicarboxylic acid solution was added to the $500 \mathrm{~mL}$ VWR pressure plus+ bottle and manually homogenized. Next, the reaction mixture was heated at $80{ }^{\circ} \mathrm{C}$ overnight in an oven. After cooling down to room temperature, the precipitate was recovered through centrifugation and washed with DMF $(3 \times 45 \mathrm{~mL}$ for $2 \mathrm{~h}$ each time $)$ followed by EtOH $(2 \times 45 \mathrm{~mL}$ for $1 \mathrm{~h}$ each time, and $1 \times 45 \mathrm{~mL}$ overnight). The product was dried under atmospheric conditions overnight. The structure of UiO-66 was confirmed by powder X-ray diffraction (PXRD) and scanning electron microscopy (SEM) analysis. Finally, UiO-66 was activated at $200{ }^{\circ} \mathrm{C}$ for $20 \mathrm{~h}$. The final product was obtained as a white solid $(0.7 \mathrm{~g}, 94 \%$ yield).

$\mathrm{Ce}_{x} \mathrm{Zr}_{(6-x)} \mathrm{O}_{4}(\mathrm{OH})_{4}(\mathrm{BDC})_{6}$. 1,4-benzenedicarboxylic acid (1.15 mmol, $191.4 \mathrm{mg}$ ) and $1.54 \mathrm{~mL}$ of concentrated formic acid were dissolved in $5.4 \mathrm{~mL}$ of DMF in a Pyrex glass reaction vial. An aqueous solution of cerium(IV) ammonium nitrate $(0.533 \mathrm{M})(1)$ and an aqueous solution of zirconium(IV) dinitrate oxide hydrate $(0.533 \mathrm{M})$ (2) were added in different ratios as indicated in Table S1, and reaction vials were heated for $15 \mathrm{~min}$ at $100{ }^{\circ} \mathrm{C}$ under continuous stirring. After cooling down, the precipitate was centrifuged and washed with DMF $(2 \times 10 \mathrm{~mL}$ for 10 min each time) and acetone (3 $\times 10 \mathrm{~mL}$ for $10 \mathrm{~min}$ each time). The product was dried for $24 \mathrm{~h}$ under atmospheric conditions. The ratio of $\mathrm{Ce} / \mathrm{Zr}$ in each $\mathrm{MOF}$ was determined with inductively coupled plasma-optical emission spectroscopy (ICP-OES) after dissolving $5 \mathrm{mg}$ of MOF in $2 \mathrm{~mL}$ of aqua regia under heating. The structure of the $\mathrm{Ce} / \mathrm{Zr}-\mathrm{UiO}-66 \mathrm{MOF}$ was 
confirmed with PXRD and SEM analysis. Finally, Ce/Zr-UiO-66 MOFs were activated at $200{ }^{\circ} \mathrm{C}$ for $18 \mathrm{~h}$.

Hydrolysis and Oxidation of Peptides. Hydrolysis Study of Glycylglycine. $900 \mu \mathrm{L}$ of $\mathrm{D}_{2} \mathrm{O}$ was mixed with $2 \mu \mathrm{mol}$ MOF and stirred for $20 \mathrm{~min} .100 \mu \mathrm{L}$ of a $20 \mathrm{mM}$ glycylglycine (GG) solution was added and $\mathrm{pD}$ was adjusted to 7.4 with $\mathrm{NaOD}$. Reactions were performed in individual vials at $60{ }^{\circ} \mathrm{C}$ and the supernatant was collected at certain time points by $2 \times 10 \mathrm{~min}$ centrifugation at 14,000 rpm. 3-(trimethylsilyl)propionic-2,2,3,3- $d_{4}$ acid sodium salt (TMSPA$d_{4}$ ) was added, and the reactions were followed with ${ }^{1} \mathrm{H}$ NMR spectroscopy. The data were fitted to a first-order decay and reaction rates were determined from the slope of the equation.

Hydrolysis Study of Gly-X. The hydrolysis of different Gly-X dipeptides was followed. $800 \mu \mathrm{L}$ of $\mathrm{D}_{2} \mathrm{O}$ was added to $2 \mu \mathrm{mol}$ MOF and mixed with $200 \mu \mathrm{L}$ of dipeptide solution $(10 \mathrm{mM})$ and the $\mathrm{pD}$ was adjusted to 7.4 with $\mathrm{NaOD}$. After $169 \mathrm{~h}$ of stirring at $60{ }^{\circ} \mathrm{C}$, the supernatant was collected, and conversion and adsorption values were determined based on ${ }^{1} \mathrm{H}$ NMR using TMSPA- $d_{4}$ as the internal standard. The hydrolysis yield of Gly-X was determined by quantification of the glycine yield in the supernatant. Adsorption of Gly-X was determined by quantification of glycine and Gly-X in solution and subtracted from the initial concentration present before the reaction.

Oxidation of Cysteine. $900 \mu \mathrm{L}$ of $\mathrm{D}_{2} \mathrm{O}$ was added to $2 \mu \mathrm{mol}$ MOF and stirred for $20 \mathrm{~min}$. $100 \mu \mathrm{L}$ of cysteine solution $(50 \mathrm{mM})$ was added and the $\mathrm{pD}$ was adjusted to 7.4 with $\mathrm{NaOD}$. Reactions were followed for $4 \mathrm{~h}$, and at certain time points, the supernatant was collected and conversion was determined based on the ${ }^{1} \mathrm{H}$ NMR yield using TMSPA- $d_{4}$ as the internal standard.

Oxidation of Cysteine in a $\mathrm{N}_{2}$ Atmosphere. $\mathrm{D}_{2} \mathrm{O}$ was degassed by purging $\mathrm{N}_{2}$ through it for $10 \mathrm{~min} .900 \mu \mathrm{L}$ of degassed $\mathrm{D}_{2} \mathrm{O}$ was added to $2 \mu \mathrm{mol} \mathrm{Ce} 61$. $100 \mu \mathrm{L}$ of a cysteine solution $(50 \mathrm{mM})$, also degassed with $\mathrm{N}_{2}$, was added and the $\mathrm{pD}$ was adjusted to 7.4 as fast as possible. The reaction was followed for $1 \mathrm{~h}$ under a continuous $\mathrm{N}_{2}$ atmosphere, the supernatant was collected, and conversion was determined based on the ${ }^{1} \mathrm{H}$ NMR yield using TMSPA- $d_{4}$ as the internal standard.

Oxidation of Tryptophan and Histidine. $900 \mu \mathrm{L}$ of $\mathrm{D}_{2} \mathrm{O}$ was added to $2 \mu \mathrm{mol} \mathrm{MOF}$ and stirred for $20 \mathrm{~min}$. $100 \mu \mathrm{L}$ of a tryptophan (Trp) or histidine (His) solution $(50 \mathrm{mM})$ was added and the $\mathrm{pD}$ was adjusted to 7.4 with $\mathrm{NaOD}$. Reactions were followed for $1-24 \mathrm{~h}$, and at certain time points, the supernatant was collected and conversion was determined based on the ${ }^{1} \mathrm{H}$ NMR yield using TMSPA- $d_{4}$ as the internal standard (Table S2).

Oxidation of Glutathione. $900 \mu \mathrm{L}$ of $\mathrm{D}_{2} \mathrm{O}$ was added to $2 \mu \mathrm{mol}$ MOF and stirred for $20 \mathrm{~min} .100 \mu \mathrm{L}$ of a glutathione solution (50 $\mathrm{mM}$ ) was added and the $\mathrm{pD}$ was adjusted to 7.4 using $\mathrm{NaOD}$. Reactions were followed for $24 \mathrm{~h}$ and conversion was determined based on the ${ }^{1} \mathrm{H}$ NMR yield using TMSPA- $d_{4}$ as the internal standard.

Further details on the protocols used are present in the Supporting Information.

\section{RESULTS AND DISCUSSION}

Hydrolysis of Glycylglycine by a Bimetallic Ce/ZrUiO-66 MOF series. In the initial step, the reactivity of pure Ce-UiO-66 MOF toward GG as a model dipeptide was studied. This MOF has good water stability in a broad $\mathrm{pH}$ range from 1 to 13 but rather low thermal stability. ${ }^{43}$ Incubation of GG with Ce-UiO-66 MOF at $60{ }^{\circ} \mathrm{C}$ and $\mathrm{pD}$ 7.4 for $24 \mathrm{~h}$ resulted in a nearly threefold increase in the rate of GG hydrolysis compared to pure $\mathrm{Zr}-\mathrm{UiO}-66 .{ }^{14}$ However, PXRD experiments of the MOF after the reaction revealed that an extra phase was formed, which may arise from the reduction of $\mathrm{Ce}(\mathrm{IV})$ to $\mathrm{Ce}(\mathrm{III})$ (see discussion below), indicating the low stability of pure Ce-UiO-66 under reaction conditions (Figure S2). To find the optimal balance between the MOF's stability and its reactivity, the bimetallic $\mathrm{Ce} / \mathrm{Zr}$-MOFs were further explored as catalysts. Compared to pure Ce-UiO-66, the bimetallic $\mathrm{Ce} / \mathrm{Zr}-\mathrm{UiO}-66 \mathrm{MOF}$ is known to have better stability, and therefore, a series of MOF catalysts with different $\mathrm{Ce} / \mathrm{Zr}$ metal ratios was synthesized in the next step. ${ }^{43}$ The structure of these MOFs were confirmed by PXRD and textural analysis and all MOFs showed a typical UiO-66 architecture (Figures $\mathrm{S} 3-\mathrm{S} 6$ and 2). The exact $\mathrm{Ce} / \mathrm{Zr}$ ratio in

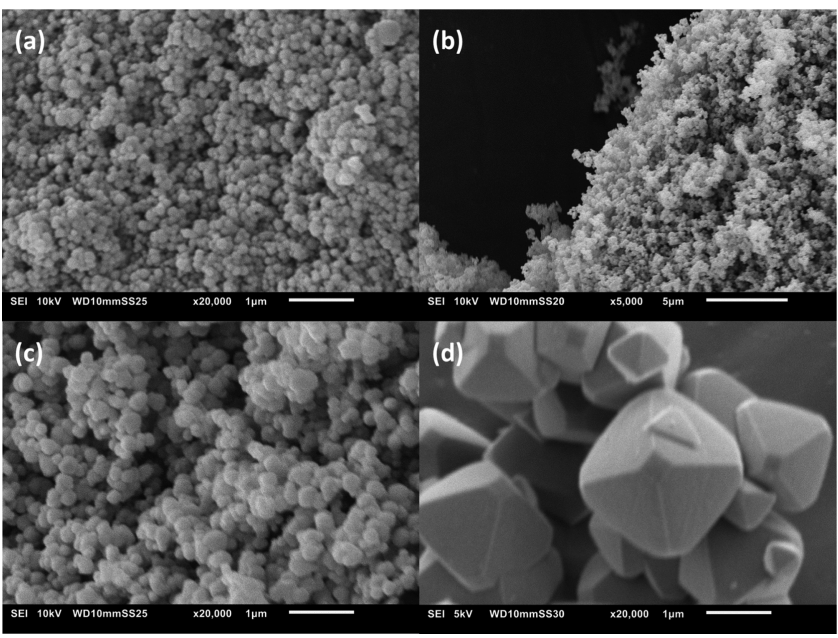

Figure 2. SEM images of the as-synthesized bimetallic Ce/Zr-UiO-66. (a) Ce28, (b) Ce43, (c) Ce61, and (d) Ce87.

the synthesized MOFs was determined using ICP-OES (Table 1 ). The Ce content in all MOFs was above $17 \%$, as under such

Table 1. Characterization of Bimetallic Ce/Zr-UiO-66 ${ }^{a}$

$\begin{array}{ccccc}\text { entry } & \text { MOF } & \text { Ce/Zr [at. \%] } & \text { diameter }(\mu \mathrm{m}) & S_{\text {BET }}\left(\mathrm{m}^{2} \mathrm{~g}^{-1}\right) \\ 1 & \text { Ce28 } & (28: 72) \pm 6 & 0.20 \pm 0.05 & 1394 \\ 2 & \text { Ce43 } & (43: 57) \pm 8 & 0.22 \pm 0.04 & 1425 \\ 3 & \text { Ce61 } & (61: 39) \pm 3 & 0.33 \pm 0.05 & 1723 \\ 4 & \text { Ce87 } & (87: 13) \pm 8 & 1.45 \pm 0.42 & 1098\end{array}$

${ }^{a} \mathrm{Ce} / \mathrm{Zr}$ [at. \%] measured with ICP-OES, diameter determined via SEM measurements (Figure 2), and the BET surface $\left(S_{\mathrm{BET}}\right)$ determined via $\mathrm{N}_{2}$ physisorption measurements (Figure S6).

conditions only $\mathrm{CeZr}_{5}$ and $\mathrm{Ce}_{6}$ clusters are present, so that consistent comparison between the ratio of these clusters could be obtained. ${ }^{58}$ The amount of Ce was systematically increased resulting in a series of four bimetallic MOFs with 28, 43, 61, and $87 \mathrm{~mol} \% \mathrm{Ce}$, which will be further referred to as Ce28, Ce43, Ce61, and Ce87, respectively. The PXRD pattern in the 7 and $25^{\circ} 2 \theta$ region showed a shift to lower diffraction angles with increasing \%Ce, which is caused by the larger size of $\mathrm{Ce}(\mathrm{IV})$ compared to that of $\mathrm{Zr}(\mathrm{IV})$ (Figure S4). Additionally, the increasing amount of Ce resulted in a larger particle size, with Ce87 having a particle diameter four to seven times larger (1.45 vs $0.20-0.33 \mathrm{~nm})$ than the other MOFs in the series (Table 1 and Figure 2). Supporting Information regarding the effect of \%Ce on the MOF surface area was obtained by $\mathrm{N}_{2}$ physisorption measurements (Figure S6), which showed a small increase in the Brunauer-Emmett-Teller (BET) surface with increasing \%Ce from Ce28 to Ce61. It should be noted that in addition to its larger particle size, Ce87 showed a decrease in the BET surface area (Table 1 entry 4), which can potentially influence the hydrolysis rates of GG. No significant difference in the amount of missing linker defects in the MOF series could be observed based on thermogravimetric analysis 
(TGA) as the calculated missing linkers, based on the literature procedure, ${ }^{59}$ are in the same range (Figure S5 and Table S4). Finally, the bimetallic $\mathrm{Ce} / \mathrm{Zr}-\mathrm{UiO}-66 \mathrm{MOFs}$ were more stable than pure $\mathrm{Ce}-\mathrm{UiO}-66$, as all bimetallic $\mathrm{Ce} / \mathrm{Zr}-\mathrm{UiO}-66 \mathrm{MOFs}$ in the obtained series have been shown to be stable under conditions used for peptide hydrolysis (see discussion below, Figure S8).

The hydrolytic activity of mixed $\mathrm{Ce} / \mathrm{Zr}-\mathrm{UiO}-66$ was probed with the model substrate GG using ${ }^{1} \mathrm{H}$ NMR spectroscopy. Hydrolysis of GG results in the formation of glycine (G) and the presence of the byproduct cyclic glycylglycine (cGG), which was also observed in the ${ }^{1} \mathrm{H}$ NMR spectra (Figures 3

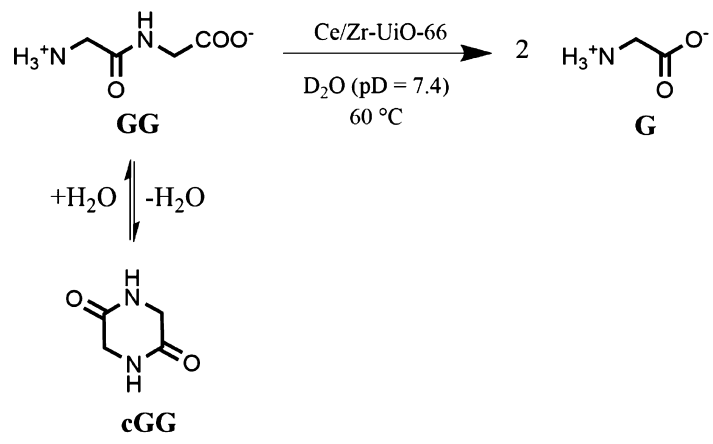

Figure 3. Hydrolysis of GG to $\mathbf{G}$ and GG cyclization to cGG in the presence of bimetallic $\mathrm{Ce} / \mathrm{Zr}-\mathrm{UiO}-66 \mathrm{MOF}$.

and S7a). The hydrolysis reaction is characterized by the decrease in GG resonance between 3.82 and 3.84 ppm, with the simultaneous increase in the $\mathbf{G}$ signal at $3.56 \mathrm{ppm}$ and an initial increase followed by a gradual decrease in the cGG signal at $4.04 \mathrm{ppm}$ (Figure S7a). For each MOF, the change in GG concentration was plotted as a function of time and the data were fitted to first-order kinetics, giving reaction rate constants as a result (Figure S7b).

Comparing the rates of GG hydrolysis for MOF samples Ce28, Ce43, and Ce61, in which \%Ce was systematically increased, revealed the importance of the $\mathrm{Ce}(\mathrm{IV})$ amount on the rate of GG hydrolysis (Figure 4). MOFs Ce28, Ce43, and Ce61 exhibit minimal variations in the particle size and BET surface (Table 1 entry $1-3$ ), which minimizes the effect of morphological features on the reaction rate. Therefore, the observed increase in the GG hydrolysis rate can be directly linked to the amount of Ce present in the MOFs. The GG hydrolysis by $\mathrm{Ce} 87$, which has the highest \%Ce, was the slowest in the series. Ce87's hydrolysis rate was 1.5 times smaller than the rate observed for Ce61, which is consistent with the lower BET surface area and bigger particle sizes observed for Ce87 in comparison with other MOFs in the series. $^{60,61}$ GG and $\mathbf{G}$ have a calculated Stoke's radius of 4.4 and $2.6 \AA$, respectively, which would allow both the substrate and product to diffuse through the pores of this MOF with diameters of 8 and $11 \AA$. The pore diameters for all MOFs in this work are similar and we can assume that the measured surface area is accessible to the substrate. Ce87 has a lower accessible surface area compared to the other MOFs, so it is less reactive toward GG hydrolysis as the amount of accessible active sites will be lower than for the other MOFs with a higher surface area. However, this effect seems to be compensated for by the high amount of $\mathrm{Ce}$ in this $\mathrm{MOF}$, resulting in similar reaction rates to those observed for $\mathrm{Ce} 43$ which has a higher $\mathrm{BET}$ surface area but a smaller amount of Ce. Interestingly, the

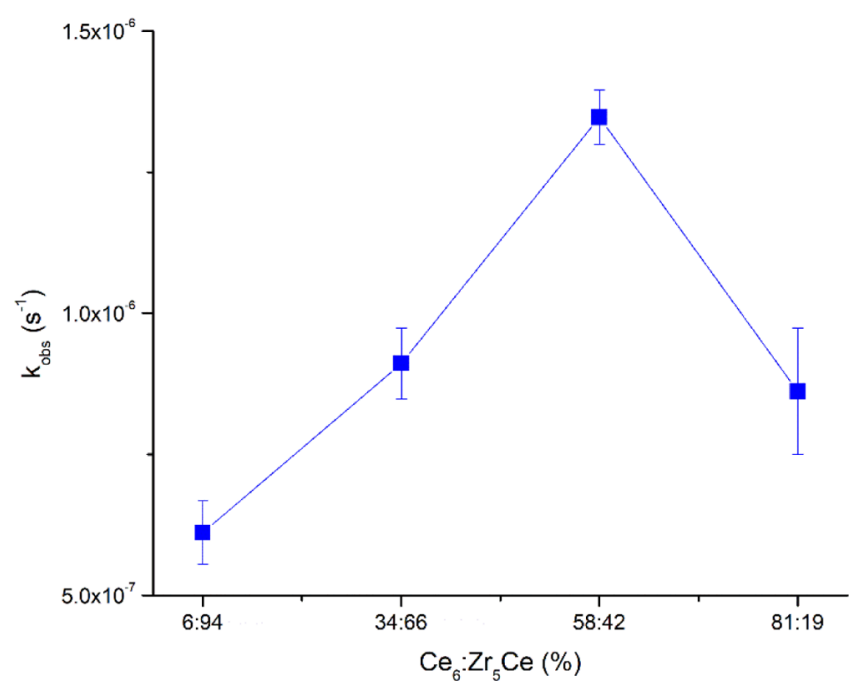

Figure 4. Effect of the ratio of $\mathrm{Ce}_{6}: \mathrm{Zr}_{5} \mathrm{Ce}$ clusters on the reaction rate of hydrolysis of GG $(2 \mu \mathrm{mol})$ by Ce/Zr-UiO-66 $\left(12 \mu \mathrm{mol} \mathrm{M} \mathrm{M}^{4+}\right)$ determined with first order kinetics. Pure $\mathrm{Zr}_{6}$ clusters are not present in the MOF series.

rate constant for GG hydrolysis observed for pure $\mathrm{Zr}-\mathrm{UiO}-66$ was very similar to that obtained for Ce28 (7.9 vs $6.11 \times 10^{-7}$ $\mathrm{s}^{-1}$, respectively), although its BET surface area is much lower compared to Ce28 $\left(861 \mathrm{~m}^{2} \mathrm{~g}^{-1}\right.$ compared to $1394 \mathrm{~m}^{2} \mathrm{~g}^{-1}$ of Ce28). ${ }^{14}$ As Ce28 consists mostly of mixed metal $\mathrm{CeZr}_{5}$ clusters (Table 2), ${ }^{58}$ it appears that this type of cluster is the least reactive. Upon increasing $\% \mathrm{Ce}$, pure $\mathrm{Ce}_{6}$ clusters (Table 2) are formed, and these are likely to be present in samples $\mathrm{Ce} 43, \mathrm{Ce} 61$, and $\mathrm{Ce} 87$ along with $\mathrm{CeZr}_{5}$ clusters. Previous DFT calculations have shown that GG binds the $\mathrm{Zr}_{6} \mathrm{O}_{8}$ cluster preferably in a bidentate manner, bridging two metal ions in one cluster and activating the carbonyl group for nucleophilic attack of a water molecule. ${ }^{62}$ The higher activity of $\mathrm{Ce}_{6}$ compared to the $\mathrm{Zr}_{6}$ cluster is consistent with the superior reactivity previously reported for $\mathrm{Ce}(\mathrm{IV})$ compared to $\mathrm{Zr}$ (IV) salts in peptide bond hydrolysis. ${ }^{27}$ The reasons for the lower reactivity of $\mathrm{CeZr}_{5}$ clusters are however still unclear and might be related to less preferred peptide coordination to two different metal centra, resulting in the decrease in the reaction rate.

When the bimetallic $\mathrm{Ce} / \mathrm{Zr}-\mathrm{UiO}-66$ samples were incubated with GG in water at $\mathrm{pD} 7.4$ and $60{ }^{\circ} \mathrm{C}$ for $24 \mathrm{~h}$, an excellent stability of all MOFs was observed by PXRD after the reaction (Figure S8). TGA further confirmed that the overall temperature stability of the MOF series was preserved (Figure S5). ICP-OES analysis of the supernatant was performed and showed only a very small amount of leached $\mathrm{Zr}(\mathrm{IV})$ (maximum $0.007 \%$ ) for all the MOFs, while only Ce87 showed a small amount $(0.005 \%)$ of Ce leached into solution (Table S10 entry 1-4). These data indicate that the hydrolysis of GG was caused by the heterogeneous MOF catalysts and was not due to soluble metal species that could have leached into solution.

Reaction Scope. The reaction scope of $\mathrm{Ce} / \mathrm{Zr}-\mathrm{UiO}-66$ catalysts was further examined using $\mathrm{Ce} 43$ as a representative example because of its high stability and intermediate particle size and BET surface. A range of different dipeptides was successfully hydrolyzed in good to excellent yields without the formation of the cyclic byproduct, revealing the selectivity of the catalyst toward hydrolysis of Gly-X bonds (Table 3). In 
Table 2. Type of Metal Clusters Present in the Bimetallic Ce/Zr-UiO-66 Series

\begin{tabular}{ccccc} 
& & Type of clusters in MOF (\%) ${ }^{\mathrm{a}}$ & \\
\hline & MOF & & $87 \pm 8$ & $13 \pm 8$ \\
2 & Ce28 & 0 & $69 \pm 10$ & $31 \pm 10$ \\
3 & $\mathrm{Ce} 43$ & 0 & $47 \pm 4$ & $53 \pm 4$ \\
4 & $\mathrm{Ce} 61$ & 0 & $16 \pm 7$ & $84 \pm 7$ \\
\hline
\end{tabular}

${ }^{a}$ Numbers are estimated based on literature ${ }^{58}$ and can slightly deviate from the real values. $\mathrm{Zr}=$ blue, $\mathrm{Ce}=$ pink.

Table 3. Yields of Peptide Bond Hydrolysis in Different Gly-X Dipeptides $(\mathrm{X}=\text { Amino Acid })^{a}$

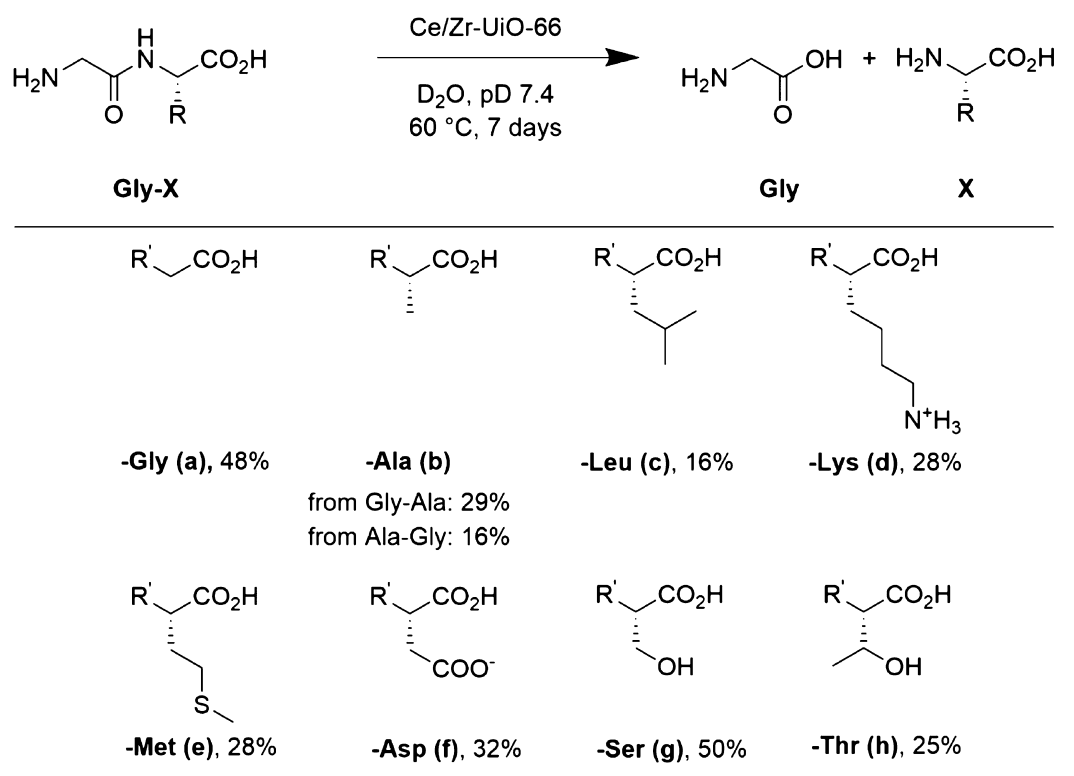

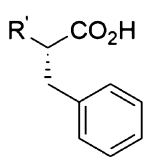

-Phe (i), $18 \%$

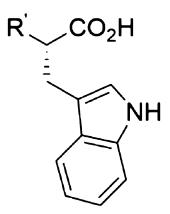

$-\operatorname{Trp}(\mathrm{j}), 24 \%$

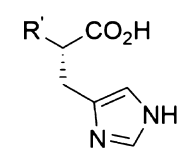

-His (k), 63\%

${ }^{a}$ Conditions: Gly-X $(2 \mu \mathrm{mol})$, Ce43 $\left(12 \mu \mathrm{mol} \mathrm{M}{ }^{4+}\right), \mathrm{D}_{2} \mathrm{O}(1 \mathrm{~mL}), 60{ }^{\circ} \mathrm{C}, \mathrm{pD} 7.4,169 \mathrm{~h} .{ }^{1} \mathrm{H}$ NMR yields of $\mathrm{G}$ in solution. $\mathrm{R}^{\prime}=-\mathrm{NH}-\mathrm{C}(=\mathrm{O})-$ $\mathrm{CH}_{2}-\mathrm{NH}_{2}$.

general, upon the incorporation of $\mathrm{Ce}(\mathrm{IV})$ in the $\mathrm{UiO}-66$ framework, the affinity trend of the type of side chain was similar to the one observed for pure $\mathrm{Zr-UiO}-66$ analogues. ${ }^{14}$ The yield of hydrolysis was highly dependent on the steric hindrance imposed by the side chains of the amino acids and decreased with the increasing bulkiness of the side chain. For example, for a series of Gly-X peptides, the yield of hydrolysis increased from $\mathrm{X}=\mathrm{Leu}(\mathbf{c})$ over $\mathrm{X}=\mathrm{Ala}(\mathbf{b})$ to $\mathrm{X}=\mathrm{Gly}(\mathbf{a})$, consistent with the proposed mechanism of peptide bond hydrolysis in which the large volume of the $\mathrm{X}$ amino acid side chain could hinder effective nucleophilic attack on the carbon atom of the peptide bond. ${ }^{62}$ Interestingly, the yield decreased when glycine was moved to the C-terminal position of the dipeptide (X-Gly peptides), as 29\% of Gly-Ala was hydrolyzed compared to $16 \%$ of Ala-Gly. This indicates that the steric hindrance at the $\mathrm{N}$-terminal position of the X-Gly dipeptide plays an even more important role in the effective hydrolysis of the peptide bond by metal centra as the coordination to the MOF cluster is hindered. Furthermore, the presence of additional amine, thioether, carboxylate, and hydroxyl groups in $\mathbf{d}, \mathbf{e}, \mathbf{f}, \mathbf{g}$, and $\mathbf{h}$ peptide substrates did not hinder hydrolysis, giving $\mathbf{G}$ in $25-50 \%$ yield, and indicating an excellent compatibility of MOF catalysts with Lewis basic functional groups.

In addition to hydrolysis, the adsorption of all peptide substrates on Ce43 has been evaluated (Table S6). The data showed that the affinity of MOF catalysts toward peptides was also greatly influenced by the nature of the amino acid's side chains. The presence of aromatic phenyl and indole groups in $\mathbf{i}$ and $\mathbf{j}$ resulted in high adsorption, most likely due to $\pi-\pi$ interactions with the linker, and also explains the lower yields observed for these substrates as they are not easily desorbed. In 

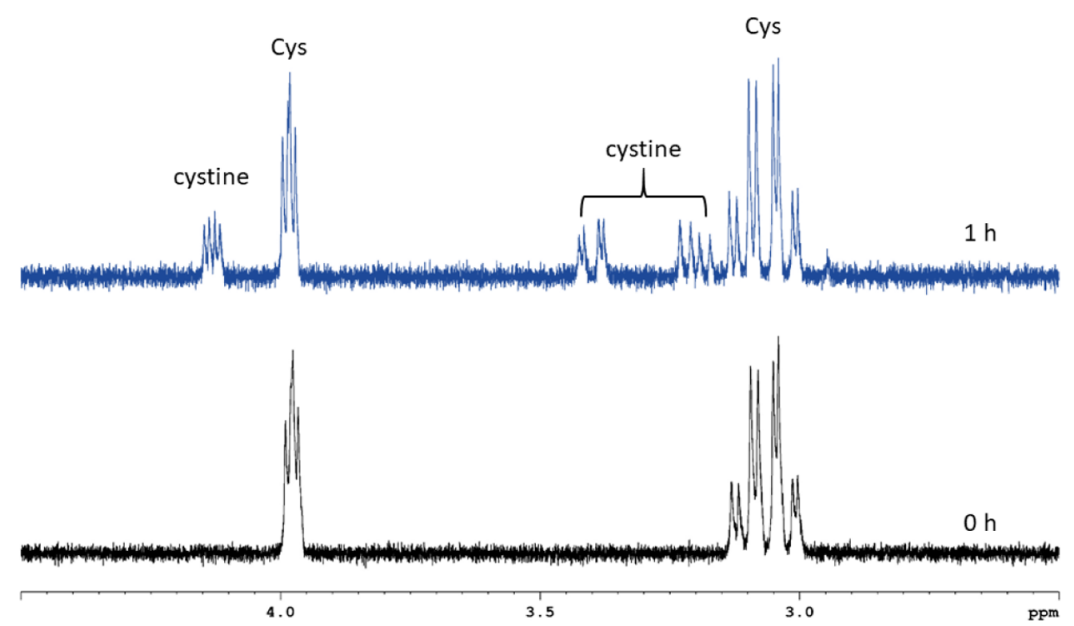

Figure 5. ${ }^{1} \mathrm{H}$ NMR spectra of the oxidation reaction of $5 \mu \mathrm{mol}$ Cys to cystine by Ce61 $\left(12 \mu \mathrm{mol} \mathrm{M} \mathrm{M}^{4+}\right)$ at room temperature and $\mathrm{pD} 7.4$. The proton NMR resonances for Cys (3.06 and $3.99 \mathrm{ppm})$ and cystine $\left(3.20,3.40\right.$, and $4.13 \mathrm{ppm}$ ) are in agreement with the previous report. ${ }^{66}$

contrast, the presence of the imidazole ring in Gly-His (k) resulted in only $9 \%$ adsorption (Table S6 entry 12). This might be due to the partially positive charge on the imidazole as its $\mathrm{pK}_{\mathrm{a}}$ value is close to the $\mathrm{pH}$ of the reaction mixture, ${ }^{63}$ making it less likely to engage in strong $\pi-\pi$ interactions with the linker. This weaker $\pi^{+}-\pi$ interaction resulted in the highest yield of reaction (63\%), showing that for efficient hydrolysis, peptide adsorption to the MOF needs to be sufficiently strong but not too strong as to prevent desorption of the substrates and products. Interestingly, the highest adsorption of $58 \%$ was observed for Gly-Asp (f), which is most likely due to the high affinity of the carboxylate group in the side chain of Asp for coordination to $\mathrm{Zr}(\mathrm{IV})$. This is in accordance with the previously shown affinity of $\mathrm{Zr}(\mathrm{IV})$ to coordinate ligands bearing carboxylate groups. ${ }^{13}$

Oxidation of Cysteine and Glutathione. Besides increasing the reactivity of the UiO-66 MOF toward peptide bond hydrolysis, the incorporation of $\mathrm{Ce}$ (IV) is likely to provide the MOF with redox activity as $\mathrm{Ce}(\mathrm{IV})$ is known to act as a one-electron oxidizing agent. ${ }^{64}$ Although $\mathrm{Ce}(\mathrm{IV})$-MOFs have been shown to oxidize thiol groups, ${ }^{54,65}$ their redox reactivity toward amino acids and peptides has not been evaluated previously. In the initial experiment, the amino acid cysteine (Cys) was used as a model substrate to evaluate the redox activity of Ce28-Ce87 MOFs. The bimetallic Ce/Zr$\mathrm{UiO}-66$ series was incubated with $\mathrm{Cys}$ at room temperature and $\mathrm{pD} 7.4$, and the reactions were monitored by ${ }^{1} \mathrm{H}$ NMR spectroscopy. The oxidation of Cys (resonances at 3.06 and $3.99 \mathrm{ppm}$ ) led to an increase of resonances at 3.20, 3.40, and $4.13 \mathrm{ppm}$ (Figure 5), which were unambiguously assigned to cystine that was formed through oxidation of the thiol group and the subsequent formation of the disulfide bond (Figure 6).

The yield of cystine formation was directly linked to the \% Ce incorporated in the MOF, with Ce87 showing 11 times higher conversion compared to Ce28 after $1 \mathrm{~h}$ of reaction

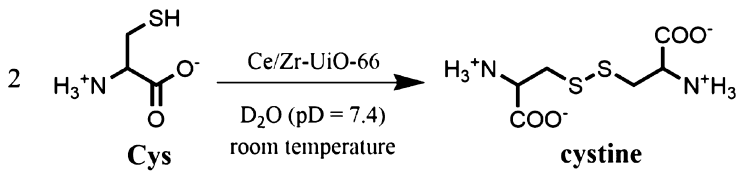

Figure 6. Oxidation of Cys to cystine in the presence of bimetallic MOF.
(Figure 7, Table S7). After 4 h of reaction, up to $76 \%$ of Cys was oxidized with Ce87 (Figure 7). Upon increasing the

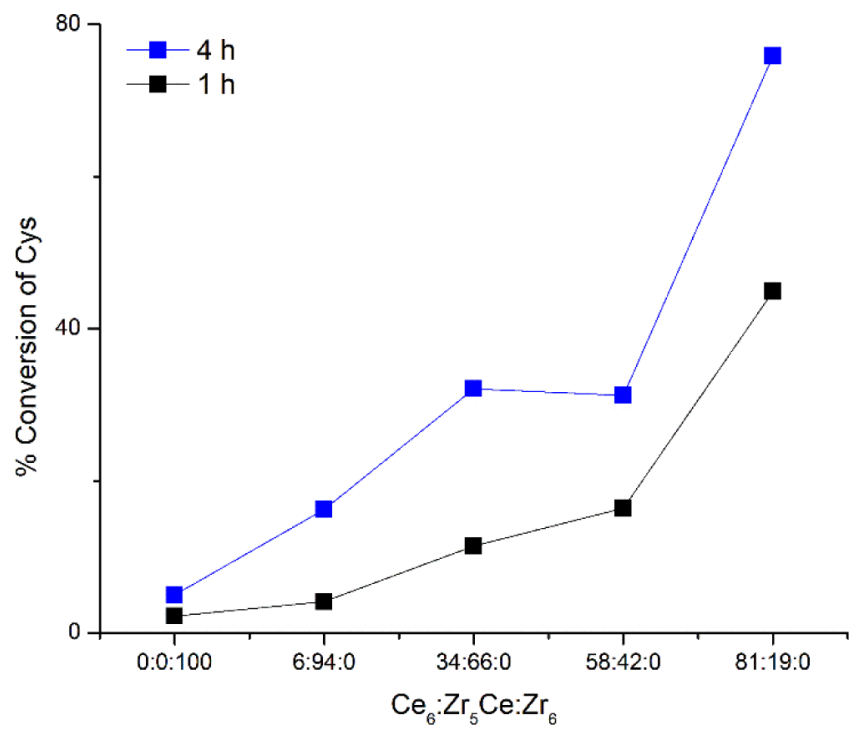

Figure 7. Influence of the ratio of $\mathrm{Ce}_{6}: \mathrm{Zr}_{5} \mathrm{Ce}: \mathrm{Zr}_{6}$ clusters on conversion of Cys $(5 \mu \mathrm{mol})$ to cystine by Ce/Zr-UiO-66 $(12 \mu \mathrm{mol}$ $\mathrm{M}^{4+}$ ), at room temperature and $\mathrm{pD} 7.4$, after $1 \mathrm{~h}$ (black) and $4 \mathrm{~h}$ (blue).

reaction time from 1 to $4 \mathrm{~h}$, the order of increase in conversion of Cys varies strongly among the MOF series (Table S8). The MOFs in the series containing higher amounts of $\mathrm{Ce}$ are less stable in oxidizing environments (see discussion below), indicating the role of $\mathrm{Zr}$ in increasing the stability and keeping the MOFs with lower Ce content reactive for longer time periods. Despite large differences in reactivity, all four MOFs outperform the commercially available catalyst $\mathrm{CeO}_{2}$ in Cys oxidation reactions (Table S7).

The stability of Ce28-Ce87 was directly correlated with the extent to which Cys was oxidized. As the yield of Cys oxidation increased, a loss of MOF structure was observed. For MOFs Ce61 and Ce87, which were the most active in the series, the changes in structure were already observed after $1 \mathrm{~h}$ (Figure S9a), while for Ce43, an additional phase was observed in the PXRD pattern only after $4 \mathrm{~h}$ of reaction (Figure S9b). From 
these data, we propose that more than one Ce(IV) per cluster may be irreversibly reduced to $\mathrm{Ce}$ (III), causing the loss of MOF structure. This was confirmed by performing a Cys oxidation reaction with Ce61 under $\mathrm{N}_{2}$ atmosphere, which prevented possible re-oxidation of $\mathrm{Ce}$ (III) to $\mathrm{Ce}(\mathrm{IV})$ by oxygen and resulted in the same yield as that under air (Table S7 entry 11-12). Previous results have shown that the MOF structure is largely preserved if only one $\mathrm{Ce}(\mathrm{IV})$ per cluster is reduced to $\mathrm{Ce}$ (III), but the reduction of additional $\mathrm{Ce}$ (IV) centers in the same cluster leads to loss of structure. ${ }^{64}$ Because a substantial amount of $\mathrm{Ce}_{6}$ clusters are present in all three of the MOFs that show a significant structural change, it is plausible to suggest that Cys oxidation occurs predominantly at these sites because the reduction of one Ce(IV) present in $\mathrm{CeZr}_{5}$ is unlikely to result in the loss of the MOF structure. Interestingly, oxidation of Cys by Ce28 resulted in $16 \%$ yield after $4 \mathrm{~h}$ (Table S7 entry 8) with no detectable loss of MOF structure (Figure $\mathrm{S} 9 \mathrm{~b}$ ). As less than $10 \% \mathrm{Ce}_{6}$ clusters are present in this MOF, these data indicate that although oxidation of Cys most likely happens preferentially at $\mathrm{Ce}_{6}$ clusters, it is also likely to occur at a mixed metal $\mathrm{CeZr}_{5}$ cluster. Despite the partial loss of MOF structure, it is important to note that these oxidation reactions occur due to the heterogeneous nature of the MOF and not due to Ce(IV) ions leached into solution. The concentrations of leached Ce were negligible, as demonstrated by ICP-OES measurements of the supernatant that was collected after the reaction (Table S10 entry 5-7).

In addition to Cys, other amino acids such as histidine (His) and tryptophan (Trp), which have previously also been shown to reduce $\mathrm{Ce}(\mathrm{IV})$ to $\mathrm{Ce}(\mathrm{III})$ in $\mathrm{Ce}(\mathrm{IV})-\mathrm{POMs}{ }^{48}$ albeit to a lesser degree than Cys, have been examined. No oxidation products could be detected in the ${ }^{1} \mathrm{H}$ NMR spectra as these amino acids tend to be regenerated by the reaction medium as was previously reported. ${ }^{48}$ Therefore, the possible reduction of $\mathrm{Ce}(\mathrm{IV})$ to $\mathrm{Ce}(\mathrm{III})$ was probably mediated by amino acids in a catalytic fashion. The same additional phase in the PXRD pattern as after oxidation of Cys was seen, suggesting reduction of $\mathrm{Ce}(\mathrm{IV})$. Although, this was only observed for reactions at enhanced reaction time and temperature $\left(24 \mathrm{~h}\right.$ and $60^{\circ} \mathrm{C}$ vs 1 $\mathrm{h}$ and room temperature for the $\mathrm{Cys}$ reaction), indicating that these reactions occurred at a much slower rate, and that $\mathrm{Ce} /$ $\mathrm{Zr}-\mathrm{UiO}-66 \mathrm{MOF}$ have the highest affinity toward oxidation of Cys (Figure S10).

To evaluate whether the oxidation reaction can occur in parallel with the hydrolytic reaction and which type of reaction would occur first, in the following step, the oxidation of the tripeptide glutathione (GSH) was followed using the same approach (Figure S11). GSH consists of three amino acids, Glu-Cys-Gly, with two peptide bonds that could undergo hydrolysis, and a free thiol group in the side chain of Cys which can be oxidized to form a disulfide bond, resulting in the GSSG product or the cystine product if oxidation is slower than hydrolysis. The Ce28-Ce87 MOFs were incubated with $5 \mu \mathrm{mol}$ GSH at room temperature and $\mathrm{pD} 7.4$ for $24 \mathrm{~h}$. At room temperature, the energy barrier for hydrolysis of the tripeptide could not be overcome, and no additional peaks arising from hydrolysis products were observed in the ${ }^{1} \mathrm{H}$ NMR spectrum. However, a decrease in GSH's ${ }^{1} \mathrm{H}$ NMR resonance was observed at $2.96 \mathrm{ppm}$, accompanied by a simultaneous increase in a resonance at $3.28 \mathrm{ppm}$ corresponding to the oxidized form GSSG, indicating that the redox reaction is favored over the hydrolytic pathway (Figure S12).
Similar to Cys oxidation, the MOFs with higher \%Ce showed higher conversion of GSH to the oxidized product GSSG (Table S9). However, the oxidation yields of the GSH tripeptide were significantly lower compared to those observed for Cys, and only MOFs Ce43-Ce87, which have higher amounts of $\mathrm{Ce}(\mathrm{IV})$, showed reactivity. This indicates that steric hindrance or unfavorable coordination to the active center imposed by additional amino acids in GSH slows down disulfide bond formation, which has been previously observed with the $\mathrm{Ce}(\mathrm{IV})$-substituted POMs. ${ }^{48}$ The pure $\mathrm{Zr-UiO}-66$ and mixed MOFs with a low amount of $\mathrm{Ce}$ (Ce28 and Ce43) showed even less conversion compared to the blank reaction, as $\mathrm{Zr}$-MOFs are known for their low oxidation ability and even for inhibiting some types of oxidation reactions. ${ }^{67}$ Interestingly, compared to the commercially available $\mathrm{CeO}_{2}, \mathrm{Ce} 61$ and $\mathrm{Ce} 87$ showed better activity toward GSH oxidation (Table S9).

The structure of all MOFs was well preserved after the reaction with GSH as shown by the PXRD patterns (Figure S13). GSH showed much lower oxidation yields than Cys, and at these low yields, it can be assumed that not more than one $\mathrm{Ce}(\mathrm{IV})$ per metal cluster may be reduced to $\mathrm{Ce}(\mathrm{III})$, preserving the MOF structure. Additionally, the concentration of leached Ce was very low (Table S10 entry 8-9), indicating that the stability and heterogeneous character of the MOFs were preserved under reaction conditions.

\section{CONCLUSIONS}

In summary, this work showcases the ability of the bimetallic nanomaterial $\mathrm{Ce} / \mathrm{Zr}-\mathrm{UiO}-66 \mathrm{MOF}$ to act as both a hydrolytic catalyst and an oxidizing agent toward peptide substrates. The amount of $\mathrm{Ce}(\mathrm{IV})$ present in the MOF nanozyme directly influences the catalytic activity toward peptide bond hydrolysis and oxidation of cysteine residues. These bimetallic $\mathrm{Ce} / \mathrm{Zr}$ UiO-66 MOFs represent an optimal balance between the stability of Zr-UiO-66 and the increased catalytic reactivity of $\mathrm{Ce}-\mathrm{UiO}-66$. The systematic analysis of different $\mathrm{Ce} / \mathrm{Zr}$ ratios suggests that $\mathrm{Ce}_{6}$ clusters have superior hydrolytic reactivity compared to the bimetallic $\mathrm{CeZr}_{5}$ sites when incorporated into this nanomaterial. Good yields were obtained with a broad scope of peptides ranging from simple dipeptides to peptides containing different functional groups in their side chains. By evaluating dipeptide adsorption onto the nanomaterials for the first time, the link between efficiency of the nanozyme and adsorption has been demonstrated. In addition, the redox activity of the bimetallic $\mathrm{Ce} / \mathrm{Zr}-\mathrm{UiO}-66$ series was most apparent in the oxidation of the thiol side chains, both in cysteine and in glutathione tripeptide, giving the first example of oxidase activity of MOFs toward biological substrates. While oxidation preferably occurs at $\mathrm{Ce}_{6}$ clusters, this work provides the first indication that $\mathrm{CeZr}_{5}$ clusters can also possess oxidative ability. In conclusion, these results demonstrate that careful tuning of the $\mathrm{Ce} / \mathrm{Zr}$ ratio in nanomaterials is a promising strategy to increase the peptidase activity and introduce oxidase activity into MOF nanozymes while preserving the MOF's stability and topology on the nanoscale. This further paves the way for applying MOFs as nanozymes in proteomics applications. We are currently investigating whether these $\mathrm{Ce} / \mathrm{Zr}$ MOFs are suitable nanozymes for the selective hydrolysis and oxidation of larger and more complex protein substrates. 


\section{ASSOCIATED CONTENT}

\section{OSupporting Information}

Synthesis of Zr-UiO-66 and bimetallic Ce/Zr-UiO-66; PXRD, ICP-OES, SEM, TGA, $\mathrm{N}_{2}$ physisorption, ${ }^{1} \mathrm{H}$ NMR, and other figures for the stability of $\mathrm{Ce} / \mathrm{Zr}-\mathrm{UiO}$ 66 and study of hydrolysis and oxidation processes (PDF)

\section{AUTHOR INFORMATION}

\section{Corresponding Author}

Tatjana N. Parac-Vogt - Laboratory of Bioinorganic Chemistry, Department of Chemistry, KU Leuven, Leuven 3001, Belgium; @ orcid.org/0000-0002-6188-3957; Email: tatjana.vogt@kuleuven.be

\section{Authors}

Alexandra Loosen - Laboratory of Bioinorganic Chemistry, Department of Chemistry, KU Leuven, Leuven 3001, Belgium; ๑ orcid.org/0000-0001-5324-6483

Charlotte Simms - Laboratory of Bioinorganic Chemistry, Department of Chemistry, KU Leuven, Leuven 3001, Belgium; ○ orcid.org/0000-0002-9334-9476

Simon Smolders - Centre for Membrane Separations, Adsorption, Catalysis and Spectroscopy for Sustainable Solutions, Department of Microbial and Molecular Systems, KU Leuven, Leuven 3001, Belgium

Dirk E. De Vos - Centre for Membrane Separations, Adsorption, Catalysis and Spectroscopy for Sustainable Solutions, Department of Microbial and Molecular Systems, KU Leuven, Leuven 3001, Belgium; ๑ orcid.org/00000003-0490-9652

\section{Author Contributions}

A.L. and C.S. contributed equally to this work. A.L. conceived the project. A.L. designed the experiments. A.L., C.S., and S.S. performed the experiments under TPV and DDV's supervision. The article was written through contributions of all authors. All authors have given approval to the final version of the article.

Notes

The authors declare no competing financial interest.

\section{ACKNOWLEDGMENTS}

A.L. thanks the FWO Flanders (Belgium) for the doctoral fellowship 48730/1S10318N. C.S. thanks the FWO Flanders (Belgium) for the doctoral fellowship 68090/11C9320N. T.P.V. and D.D.V. thank the FWO Flanders (Belgium) for funding under the project G095017N. T.P.V. thanks the European Commission for the funding under the Horizon 2020, FoodEnTwin project, GA no. 810752. The authors thank Dr. Francisco de Azambuja for useful suggestions during the preparation of this article.

\section{REFERENCES}

(1) Lee, J.; Farha, O. K.; Roberts, J.; Scheidt, K. A.; Nguyen, S. T.; Hupp, J. T. Metal-organic framework materials as catalysts. Chem. Soc. Rev. 2009, 38, 1450-1459.
(2) Furukawa, H.; Cordova, K. E.; O’Keeffe, M.; Yaghi, O. M. The chemistry and applications of metal-organic frameworks. Science 2013, 341, 1230444.

(3) Canivet, J.; Fateeva, A.; Guo, Y.; Coasne, B.; Farrusseng, D. Water adsorption in MOFs: fundamentals and applications. Chem. Soc. Rev. 2014, 43, 5594-5617.

(4) An, J.; Rosi, N. L. Tuning MOF CO2 adsorption properties via cation exchange. J. Am. Chem. Soc. 2010, 132, 5578-5579.

(5) Deria, P.; Mondloch, J. E.; Tylianakis, E.; Ghosh, P.; Bury, W.; Snurr, R. Q.; Hupp, J. T.; Farha, O. K. Perfluoroalkane functionalization of NU-1000 via solvent-assisted ligand incorporation: synthesis and $\mathrm{CO} 2$ adsorption studies. J. Am. Chem. Soc. 2013, $135,16801-16804$.

(6) Horcajada, P.; Chalati, T.; Serre, C.; Gillet, B.; Sebrie, C.; Baati, T.; Eubank, J. F.; Heurtaux, D.; Clayette, P.; Kreuz, C.; Chang, J.-S.; Hwang, Y. K.; Marsaud, V.; Bories, P.-N.; Cynober, L.; Gil, S.; Férey, G.; Couvreur, P.; Gref, R. Porous metal-organic-framework nanoscale carriers as a potential platform for drug delivery and imaging. Nat. Mater. 2010, 9, 172.

(7) Shieh, F.-K.; Wang, S.-C.; Yen, C.-I.; Wu, C.-C.; Dutta, S.; Chou, L.-Y.; Morabito, J. V.; Hu, P.; Hsu, M.-H.; Wu, K. C.-W.; Tsung, C.-K. Imparting functionality to biocatalysts via embedding enzymes into nanoporous materials by a de novo approach: size-selective sheltering of catalase in metal-organic framework microcrystals. J. Am. Chem. Soc. 2015, 137, 4276-4279.

(8) Lammert, M.; Wharmby, M. T.; Smolders, S.; Bueken, B.; Lieb, A.; Lomachenko, K. A.; Vos, D. D.; Stock, N. Cerium-based metal organic frameworks with UiO-66 architecture: synthesis, properties and redox catalytic activity. Chem. Commun. 2015, 51, 12578-12581.

(9) Smolders, S.; Willhammar, T.; Krajnc, A.; Sentosun, K.; Wharmby, M. T.; Lomachenko, K. A.; Bals, S.; Mali, G.; Roeffaers, M. B. J.; De Vos, D. E.; Bueken, B. A Titanium(IV)-Based MetalOrganic Framework Featuring Defect-Rich Ti-O Sheets as an Oxidative Desulfurization Catalyst. Angew. Chem. 2019, 131, 92589263.

(10) Van Velthoven, N.; Waitschat, S.; Chavan, S. M.; Liu, P.; Smolders, S.; Vercammen, J.; Bueken, B.; Bals, S.; Lillerud, K. P.; Stock, N.; De Vos, D. E. Single-site metal-organic framework catalysts for the oxidative coupling of arenes via $\mathrm{C}-\mathrm{H} / \mathrm{C}-\mathrm{H}$ activation. Chem. Sci. 2019, 10, 3616-3622.

(11) Agarwal, R. A.; Gupta, A. K.; De, D. Flexible Zn-MOF exhibiting selective $\mathrm{CO} 2$ adsorption and efficient Lewis acidic catalytic activity. Cryst. Growth Des. 2019, 19, 2010-2018.

(12) Loosen, A.; de Azambuja, F.; Smolders, S.; Moons, J.; Simms, C.; De Vos, D.; Parac-Vogt, T. N. Interplay between structural parameters and reactivity of Zr6-based MOFs as artificial proteases. Chem. Sci. 2020, 11, 6662-6669.

(13) Ly, H. G. T.; Fu, G.; Kondinski, A.; Bueken, B.; De Vos, D.; Parac-Vogt, T. N. Superactivity of MOF-808 toward Peptide Bond Hydrolysis. J. Am. Chem. Soc. 2018, 140, 6325-6335.

(14) Ly, H. G. T.; Fu, G.; de Azambuja, F.; De Vos, D.; Parac-Vogt, T. N. Nanozymatic Activity of UiO-66 Metal-Organic Frameworks: Tuning the Nanopore Environment Enhances Hydrolytic Activity toward Peptide Bonds. ACS Appl. Nano Mater. 2020, 3, 8931-8938.

(15) Grant, K.; Kassai, M. Major Advances in the Hydrolysis of Peptides and Proteins by Metal Ions and Complexes. Curr. Org. Chem. 2006, 10, 1035-1049.

(16) Wezynfeld, N. E.; Frączyk, T.; Bal, W. Metal assisted peptide bond hydrolysis: Chemistry, biotechnology and toxicological implications. Coord. Chem. Rev. 2016, 327-328, 166-187.

(17) Yashiro, M.; Sonobe, Y.; Yamamura, A.; Takarada, T.; Komiyama, M.; Fujii, Y. Metal-ion-assisted hydrolysis of dipeptides involving a serine residue in a neutral aqueous solution. Org. Biomol. Chem. 2003, 1, 629-632.

(18) Kassai, M.; Grant, K. B. Tuning Zr (IV)-assisted peptide hydrolysis at near-neutral pH. Inorg. Chem. Commun. 2008, 11, 521525.

(19) Kopera, E.; Krężel, A.; Protas, A. M.; Belczyk, A.; Bonna, A.; Wysłouch-Cieszyńska, A.; Poznański, J.; Bal, W. Sequence-specific Ni 
(II)-dependent peptide bond hydrolysis for protein engineering: reaction conditions and molecular mechanism. Inorg. Chem. 2010, 49, 6636-6645.

(20) Belczyk-Ciesielska, A.; Zawisza, I. A.; Mital, M.; Bonna, A.; Bal, W. Sequence-specific $\mathrm{Cu}$ (II)-dependent peptide bond hydrolysis: similarities and differences with the $\mathrm{Ni}$ (II)-dependent reaction. Inorg. Chem. 2014, 53, 4639-4646.

(21) Jeon, J. W.; Son, S. J.; Yoo, C. E.; Hong, I. S.; Suh, J. Toward protein-cleaving catalytic drugs: Artificial protease selective for myoglobin. Bioorg. Med. Chem. 2003, 11, 2901-2910.

(22) Zhu, L.; Qin, L.; Parac, T. N.; Kostic, N. M. Site-specific hydrolytic cleavage of cytochrome $\mathrm{c}$ and of its heme undecapeptide, promoted by coordination complexes of palladium (II). J. Am. Chem. Soc. 1994, 116, 5218-5224.

(23) Parac, T. N.; Kostić, N. M. Effects of linkage isomerism and of acid- base equilibria on reactivity and catalytic turnover in hydrolytic cleavage of histidyl peptides coordinated to Palladium (II). identification of the active complex between Palladium (II) and the histidyl residue. J. Am. Chem. Soc. 1996, 118, 5946-5951.

(24) Parac, T. N.; Kostić, N. M. New selectivity and turnover in peptide hydrolysis by metal complexes. A palladium (II) aqua complex catalyzes cleavage of peptides next to the histidine residue. $J$. Am. Chem. Soc. 1996, 118, 51-58.

(25) Parac, T. N.; Kostic, N. M. Regioselective cleavage by a palladium (II) aqua complex of a polypeptide in different overall conformations. Inorg. Chem. 1998, 37, 2141-2144.

(26) Parac, T. N.; Ullmann, G. M.; Kostić, N. M. New regioselectivity in the cleavage of histidine-containing peptides by palladium (II) complexes studied by kinetic experiments and molecular dynamics simulations. J. Am. Chem. Soc. 1999, 121, $3127-3135$.

(27) Takarada, T.; Yashiro, M.; Komiyama, M. Catalytic hydrolysis of peptides by cerium (IV). Chem.-Eur. J. 2000, 6, 3906-3913.

(28) Grant, I.; Hay, R. Copper (II) catalysis of the hydrolysis of glycylglycine. Aust. J. Chem. 1965, 18, 1189-1195.

(29) Rana, T. M.; Meares, C. F. Specific cleavage of a protein by an attached iron chelate. J. Am. Chem. Soc. 1990, 112, 2457-2458.

(30) Singhal, A.; Toth, L. M.; Lin, J. S.; Affholter, K. Zirconium (IV) tetramer/octamer hydrolysis equilibrium in aqueous hydrochloric acid solution. J. Am. Chem. Soc. 1996, 118, 11529-11534.

(31) Clearfield, A. The mechanism of hydrolytic polymerization of zirconyl solutions,. J. Mater. Res. 1990, 5, 161-162.

(32) Absillis, G.; Parac-Vogt, T. N. Peptide bond hydrolysis catalyzed by the Wells-Dawson $\mathrm{Zr}(\alpha 2$-P2W17O61) 2 polyoxometalate. Inorg. Chem. 2012, 51, 9902-9910.

(33) Vanhaecht, S.; Absillis, G.; Parac-Vogt, T. N. Amino acid side chain induced selectivity in the hydrolysis of peptides catalyzed by a $\mathrm{Zr}(\mathrm{IV})$-substituted Wells-Dawson type polyoxometalate. Dalton Trans. 2013, 42, 15437-15446.

(34) Stroobants, K.; Absillis, G.; Moelants, E.; Proost, P.; ParacVogt, T. N. Regioselective hydrolysis of human serum albumin by $\mathrm{Zr}(\mathrm{IV})$-substituted polyoxotungstates at the interface of positively charged protein surface patches and negatively charged amino acid residues. Chem.-Eur. J. 2014, 20, 3894-3897.

(35) Sap, A.; Absillis, G.; Parac-Vogt, T. N. Selective hydrolysis of oxidized insulin chain B by a $\mathrm{Zr}(\mathrm{IV})$-substituted Wells-Dawson polyoxometalate. Dalton Trans. 2015, 44, 1539-1548.

(36) Quanten, T.; Shestakova, P.; Van Den Bulck, D.; Kirschhock, C.; Parac-Vogt, T. N. Interaction Study and Reactivity of ZrIVSubstituted Wells-Dawson Polyoxometalate towards Hydrolysis of Peptide Bonds in Surfactant Solutions. Chem.-Eur. J. 2016, 22, $3775-3784$

(37) Van Rompuy, L. S.; Savić, N. D.; Rodriguez, A.; Parac-Vogt, T. N. Selective Hydrolysis of Transferrin Promoted by Zr-Substituted Polyoxometalates. Molecules 2020, 25, 3472.

(38) Quanten, T.; Savić, N. D.; Parac-Vogt, T. N. Hydrolysis of Peptide Bonds in Protein Micelles Promoted by a Zirconium(IV)Substituted Polyoxometalate as an Artificial Protease. Chem.-Eur. J. 2020, 26, 11170-11179.
(39) Moons, J.; Azambuja, F.; Mihailovic, J.; Kozma, K.; Smiljanic, K.; Amiri, M.; Cirkovic Velickovic, T.; Nyman, M.; Parac-Vogt, T. N. Discrete Hf 18 Metal-oxo Cluster as a Heterogeneous Nanozyme for Site-Specific Proteolysis. Angew. Chem. 2020, 132, 9179-9186.

(40) Zhang, L.; Liu, Z.; Deng, Q.; Sang, Y.; Dong, K.; Ren, J.; Qu, X. Nature-Inspired Construction of MOF@ COF Nanozyme with Active Sites in Tailored Microenvironment and Pseudopodia-Like Surface for Enhanced Bacterial Inhibition. Angew. Chem., Int. Ed. 2021, 60, 3469-3474.

(41) Radzicka, A.; Wolfenden, R. Rates of uncatalyzed peptide bond hydrolysis in neutral solution and the transition state affinities of proteases. J. Am. Chem. Soc. 1996, 118, 6105-6109.

(42) Ahmed, I.; Adhikary, K. K.; Lee, Y.-R.; Ho Row, K.; Kang, K.K.; Ahn, W.-S. Ionic liquid entrapped UiO-66: Efficient adsorbent for Gd3+ capture from water. Chem. Eng. J. 2019, 370, 792-799.

(43) Lammert, M.; Glissmann, C.; Stock, N. Tuning the stability of bimetallic $\mathrm{Ce}(\mathrm{IV}) / \mathrm{Zr}(\mathrm{IV})$-based MOFs with UiO-66 and MOF-808 structures. Dalton Trans. 2017, 46, 2425-2429.

(44) Cavka, J. H.; Jakobsen, S.; Olsbye, U.; Guillou, N.; Lamberti, C.; Bordiga, S.; Lillerud, K. P. A new zirconium inorganic building brick forming metal organic frameworks with exceptional stability. J. Am. Chem. Soc. 2008, 130, 13850-13851.

(45) Zhang, Y.-F.; Wang, Q.; Xue, D.-X.; Bai, J. Single-Crystal Synthesis and Diverse Topologies of Hexanuclear CeIV-Based MetalOrganic Frameworks. Inorg. Chem. 2020, 59, 11233-11237.

(46) Moons, J.; Van Rompuy, L. S.; Abdelhameed, S. A. M.; Simons, W.; Parac-Vogt, T. N.; Parac-Vogt, T. N. Hydrolysis of transferrin promoted by a cerium (IV)-Keggin polyoxometalate. Polyhedron 2019, 170, 570-575.

(47) Sap, A.; Van Tichelen, L.; Mortier, A.; Proost, P.; Parac-Vogt, T. N. Tuning the Selectivity and Reactivity of Metal-Substituted Polyoxometalates as Artificial Proteases by Varying the Nature of the Embedded Lewis Acid Metal Ion. Eur. J. Inorg. Chem. 2016, 2016, 5098-5105.

(48) Abdelhameed, S. A. M.; Vandebroek, L.; de Azambuja, F.; Parac-Vogt, T. N. Redox Activity of Ce (IV)-Substituted Polyoxometalates toward Amino Acids and Peptides. Inorg. Chem. 2020, 59, 10569-10577.

(49) Quanten, T.; De Mayaer, T.; Shestakova, P.; Parac-Vogt, T. N. Selectivity and reactivity of ZrIV and CeIV substituted Keggin type polyoxometalates toward cytochrome $\mathrm{c}$ in surfactant solutions. Front. Chem. 2018, 6, 372.

(50) Stroobants, K.; Moelants, E.; Ly, H. G. T.; Proost, P.; Bartik, K.; Parac-Vogt, T. N. Polyoxometalates as a novel class of artificial proteases: selective hydrolysis of lysozyme under physiological $\mathrm{pH}$ and temperature promoted by a cerium(IV) Keggin-type polyoxometalate. Chem.-Eur. J. 2013, 19, 2848-2858.

(51) Islamoglu, T.; Atilgan, A.; Moon, S.-Y.; Peterson, G. W.; DeCoste, J. B.; Hall, M.; Hupp, J. T.; Farha, O. K. Cerium (IV) vs zirconium (IV) based metal-organic frameworks for detoxification of a nerve agent. Chem. Mater. 2017, 29, 2672-2675.

(52) Geravand, E.; Farzaneh, F.; Gil-San-Millan, R.; Carmona, F. J.; Navarro, J. A. R. Mixed-Metal Cerium/Zirconium MOFs with Improved Nerve Agent Detoxification Properties. Inorg. Chem. 2020, 59, 16160-16167.

(53) Dalapati, R.; Sakthivel, B.; Dhakshinamoorthy, A.; Buragohain, A.; Bhunia, A.; Janiak, C.; Biswas, S. A highly stable dimethylfunctionalized $\mathrm{Ce}$ (iv)-based UiO-66 metal-organic framework material for gas sorption and redox catalysis. CrystEngComm 2016, $18,7855-7864$.

(54) Dalapati, R.; Sakthivel, B.; Ghosalya, M. K.; Dhakshinamoorthy, A.; Biswas, S. A cerium-based metal-organic framework having inherent oxidase-like activity applicable for colorimetric sensing of biothiols and aerobic oxidation of thiols. CrystEngComm 2017, 19, 5915-5925.

(55) Prabhulkar, S.; Tian, H.; Wang, X.; Zhu, J.-J.; Li, C.-Z. Engineered proteins: redox properties and their applications. Antioxid. Redox Signaling 2012, 17, 1796-1822. 
(56) Abdelhamid, H. N.; Mahmoud, G. A.-E.; Sharmouk, W. A cerium-based MOFzyme with multi-enzyme-like activity for the disruption and inhibition of fungal recolonization. J. Mater. Chem. B 2020, 8, 7548-7556.

(57) Valenzano, L.; Civalleri, B.; Chavan, S.; Bordiga, S.; Nilsen, M. H.; Jakobsen, S.; Lillerud, K. P.; Lamberti, C. Disclosing the complex structure of UiO-66 metal organic framework: a synergic combination of experiment and theory. Chem. Mater. 2011, 23, 1700-1718.

(58) Lomachenko, K. A.; Jacobsen, J.; Bugaev, A. L.; Atzori, C.; Bonino, F.; Bordiga, S.; Stock, N.; Lamberti, C. Exact stoichiometry of CexZr6-x cornerstones in mixed-metal UiO-66 MOFs revealed by EXAFS spectroscopy. J. Am. Chem. Soc. 2018, 140, 17379-17383.

(59) Shearer, G. C.; Chavan, S.; Bordiga, S.; Svelle, S.; Olsbye, U.; Lillerud, K. P. Defect Engineering: Tuning the Porosity and Composition of the Metal-Organic Framework UiO-66 via Modulated Synthesis. Chem. Mater. 2016, 28, 3749-3761.

(60) Tonigold, M.; Lu, Y.; Bredenkötter, B.; Rieger, B.; Bahnmüller, S.; Hitzbleck, J.; Langstein, G.; Volkmer, D. Heterogeneous catalytic oxidation by MFU-1: a cobalt(II)-containing metal-organic framework. Angew. Chem., Int. Ed. 2009, 48, 7546-7550.

(61) Li, P.; Klet, R. C.; Moon, S.-Y.; Wang, T. C.; Deria, P.; Peters, A. W.; Klahr, B. M.; Park, H.-J.; Al-Juaid, S. S.; Hupp, J. T.; Farha, O. $\mathrm{K}$. Synthesis of nanocrystals of $\mathrm{Zr}$-based metal-organic frameworks with csq-net: significant enhancement in the degradation of a nerve agent simulant. Chem. Commun. 2015, 51, 10925-10928.

(62) Conic, D.; Pierloot, K.; Parac-Vogt, T. N.; Harvey, J. N. Mechanism of the Highly Effective Peptide Bond Hydrolysis by MOF-808 Catalyst Under Biologically Relevant Conditions. Phys. Chem. Chem. Phys. 2020, 22, 25136-25145.

(63) Loewenthal, R.; Sancho, J.; Fersht, A. R. Histidine-aromatic interactions in barnase: Elevation of histidine $\mathrm{pKa}$ and contribution to protein stability. J. Mol. Biol. 1992, 224, 759-770.

(64) Smolders, S.; Lomachenko, K. A.; Bueken, B.; Struyf, A.; Bugaev, A. L.; Atzori, C.; Stock, N.; Lamberti, C.; Roeffaers, M. B. J.; De Vos, D. E. Unravelling the Redox-catalytic Behavior of $\mathrm{Ce}(4+)$ Metal-Organic Frameworks by X-ray Absorption Spectroscopy. ChemPhysChem 2018, 19, 373-378.

(65) Nie, L.; Ma, H.; Sun, M.; Li, X.; Su, M.; Liang, S. Direct chemiluminescence determination of cysteine in human serum using quinine-Ce (IV) system. Talanta 2003, 59, 959-964.

(66) Nakayama, T.; Isobe, T.; Nakamiya, K.; Edmonds, J. S.; Shibata, Y.; Morita, M. Complexes of diphenylarsinic acid and phenylarsonic acid with thiols: a $1 \mathrm{H}$ and 13C NMR study. Magn. Reson. Chem. 2005, 43, 543-550.

(67) Nguyen, H. G. T.; Mao, L.; Peters, A. W.; Audu, C. O.; Brown, Z. J.; Farha, O. K.; Hupp, J. T.; Nguyen, S. T. Comparative study of titanium-functionalized UiO-66: support effect on the oxidation of cyclohexene using hydrogen peroxide. Catal. Sci. Technol. 2015, 5, 4444-4451. 